Robert ZAJDLER ${ }^{1}$

\title{
UWAGI KRYTYCZNE DO REGULACJI „OBLIGA GIELDOWEGO" JAKO SPOSOBU BUDOWANIA HURTOWEGO RYNKU GAZU ZIEMNEGO W POLSCE
}

\begin{abstract}
Celem artykułu jest analiza prawna przyjętych rozwiązań regulacyjnych w zakresie obowiązku sprzedaży zdefiniowanych ilości gazu ziemnego wysokometanowego przez określone w ustawie podmioty na giełdach towarowych lub na rynku organizowanym przez podmiot prowadzący na terytorium Rzeczypospolitej Polskiej rynek regulowany. Wymiar tego obowiązku jest znaczący. Zobowiązany podmiot powinien sprzedać gaz ziemny w ramach tego mechanizmu w ilości nie mniejszej niż 30\% w 2013 r., 40\% w 2014 r. i 55\% w 2015 r. i w latach następnych. Brak jego realizacji grozi karą finansową do $15 \%$ przychodów z działalności prowadzonej na podstawie koncesji w poprzednim roku podatkowym. Te rozwiązania prawne rodzą wątpliwości natury konstytucyjnej, administracyjnoprawnej oraz cywilnoprawnej w zakresie dopuszczalności przyjętego sposobu regulacji stosunków umownych. Niejasność niektórych pojęć i przyjętych rozwiązań sprawia, że zakładany ich skutek może nie zostać osiagnięty, a koszty ich wprowadzenia mogą negatywnie oddziaływać na rynek i jego uczestników.

Rozważania osadzone są również w kontekście uwarunkowań rynku gazu ziemnego Unii Europejskiej oraz struktury rynku krajowego. Zaproponowany przez ustawodawcę model obrotu na rynku hurtowym jest odmienny od tego obserwowanego w innych państwach członkowskich Unii Europejskiej, co może powodować bariery w dalszym rozwoju rynku i integracji rynku krajowego $\mathrm{z}$ rynkiem Unii Europejskiej. W artykule zaprezentowano sugerowane rozwiązania prawne, które w ocenie autora mogą dostosować wprowadzony model do tego istniejącego w Unii Europejskiej.

Slowa kluczowe: gaz ziemny, liberalizacja, rynek gazu Unii Europejskiej, taryfy, obligo giełdowe, rynek hurtowy.
\end{abstract}

\section{WPROWADZENIE}

W Polsce 11 wrześniu 2013 r. zaczęła obowiązywać nowelizacja ustawy Prawo energetyczne ${ }^{2}$, która wprowadziła tzw. „obligo giełdowe” na rynku gazu ziemnego, czyli obowiązek sprzedaży zdefiniowanych ilości gazu ziemnego wysokometanowego przez określone $\mathrm{w}$ ustawie podmioty na giełdach towarowy $\mathrm{ch}^{3}$ lub na rynku organizowanym przez podmiot prowadzący na terytorium Rzeczypospolitej Polskiej rynek regulowany ${ }^{4}$,

1 Dr Robert Zajdler, Wydzial Administracji i Nauk Społecznych, Politechnika Warszawska, radca prawny - kancelaria prawna Zajdler Energy Lawyers, e-mail: info@ zajdler.eu

2 Ustawa z 10 kwietnia 1997 r. Prawo energetyczne (Dz. U 2012 nr 1059 jt. ze zm.). Nowelizacja wprowadzona ustawą z 26 lipca 2013 r. o zmianie ustawy - Prawo energetyczne oraz niektórych innych ustaw (Dz. U $2013 \mathrm{nr}$ 984; dalej: ustawa PE).

$3 \mathrm{~W}$ rozumieniu art. 2 pkt 1 ustawy z 26 października 2000 r. o giełdach towarowych (Dz. U 2014 nr 197 jt.).

$4 \mathrm{~W}$ rozumieniu art. 14 ust. ustawy z 29 lipca 2005 r. o obrocie instrumentami finansowymi (Dz. U 2014 nr 94 jt.). 
począwszy od dnia wejścia w życie ustawy ${ }^{5}$. Wymiar tego obowiązku jest znaczący. Zobowiązany podmiot powinien sprzedać gaz ziemny $\mathrm{w}$ ramach tego mechanizmu $\mathrm{w}$ ilości nie mniejszej niż 30\% w 2013 r., 40\% w 2014 r. i 55\% w 2015 r. i w latach następnych. Brak jego realizacji jest zagrożony karą finansową do $15 \%$ przychodów z działalności prowadzonej na podstawie koncesji w poprzednim roku podatkowym.

Wprowadzenie takiego obowiązku na rynku gazu ziemnego jest unikatowym rozwiązaniem w skali Unii Europejskiej ${ }^{6}$ (UE), jeżeli chodzi o zaproponowany model regulacyjny, skalę nałożonego obowiązku, zakres podmiotów zobowiązanych oraz okres przewidziany na wdrożenie tych rozwiązań. Mechanizm ten istotnie ingeruje w strukturę rynku gazu ziemnego oraz $\mathrm{w}$ zobowiązania umowne przedsiębiorstw energetycznych ${ }^{7}$. Rozwiązanie to wpływa również na model rynku hurtowego gazu ziemnego w Polsce. Wymuszenie obrotu giełdowego na takim poziomie sprawia, że obrót gazem ziemnym w ramach innych form obrotu, takich jak umowy dwustronne, jest ograniczony. Ma to znaczenie w procesie integracji hurtowego rynku gazu w Polsce z rynkami innych państw członkowskich Unii Europejskiej.

Celem niniejszego artykułu będzie przyjrzenie się zaproponowanym zmianom prawnym z punktu widzenia ich znaczenia dla uczestników rynku oraz dla budowy hurtowego rynku gazu ziemnego w Polsce. Analizę osadzono w uwarunkowaniach prawnych wynikających $\mathrm{z}$ regulacji prawa polskiego i prawa Unii Europejskiej oraz w uwarunkowaniach ekonomicznych wynikających $\mathrm{z}$ obecnej struktury rynku gazu ziemnego w Polsce i w Unii Europejskiej. Stan prawny i faktyczny obowiązywał na 30 maja $2014 \mathrm{r}$

\section{ZAKRES REGULACJI}

Zgodnie $\mathrm{z}$ art. 49b ustawy PE przedsiębiorstwo energetyczne zajmujące się obrotem paliwami gazowymi jest obowiązane sprzedawać na giełdach towarowych lub na rynku organizowanym przez podmiot prowadzący na terytorium Rzeczypospolitej Polskiej rynek regulowany nie mniej niż 55\% gazu ziemnego wysokometanowego wprowadzonego $\mathrm{W}$ danym roku do sieci przesyłowej: (1) w punktach wejścia do krajowego systemu przesyłowego na połączeniach z systemami przesyłowymi innych państw lub (2) siecią gazociągów kopalnianych, lub (3) terminalami skroplonego gazu ziemnego. Obowiązek ten został ograniczony do $30 \%$ w 2013 r. i 40\% w 2014 r. $^{8}$.

Z obowiązku wyłączone są te ilości gazu ziemnego wysokometanowego, które: (1) stanowią zapasy obowiązkowe gazu ziemnego ${ }^{9},(2)$ odpowiadają ilości gazu ziemnego w

5 Ze względu na obecny kształt rynku hurtowego gazu ziemnego przepis umożliwiający handel na giełdzie towarowej lub na rynku regulowanym dotyczy w praktyce wyłącznie jednego podmiotu, czyli Towarowej Giełdy Energii S.A. (dalej: TGE). Dlatego też w dalszej części publikacji używane będzie ich zbiorcze określenie „giełda”.

6 Szerzej R. Zajdler, Polski rynek hurtowy gazu ziemnego na tle rynków Unii Europejskiej, Warszawa 2014.

7 Zgodnie z art. 3 pkt 12 ustawy z 10 kwietnia 1997 r. Prawo energetyczne, przez ,przedsiębiorstwo energetyczne" rozumie się podmiot prowadzący działalność gospodarczą w zakresie: (a) wytwarzania, przetwarzania, magazynowania, przesyłania, dystrybucji paliw albo energii lub obrotu nimi albo (b) przesyłania dwutlenku węgla.

8 Zgodnie z art. 25 ustawy z 26 lipca 2013 r. o zmianie ustawy - Prawo energetyczne oraz niektórych innych ustaw (Dz. U $2013 \mathrm{nr} 984$ ).

$9 \mathrm{~W}$ rozumieniu art. 24 ustawy z 16 lutego 2007 r. o zapasach ropy naftowej, produktów naftowych 
tranzycie, (3) są przeznaczane na określone potrzeby operatorów systemów gazowych (przesyłowego, dystrybucyjnego, magazynowego i LNG) czy też (4) są wykorzystywane na potrzeby własne danego przedsiębiorstwa, to jest niebędące przedmiotem sprzedaży w rozumieniu ustawy $\mathrm{PE}$.

Zgodnie $\mathrm{z}$ art. $49 \mathrm{~b}$ ust. 3 ustawy PE z obowiązku zwolnione są te podmioty zajmujące się obrotem gazem ziemnym $\mathrm{z}$ zagranicą, które $\mathrm{W}$ danym roku mają prawo do przepustowości na punktach wejścia do krajowego systemu przesyłowego w ilości mniejszej niż 10\% całkowitej wielkości przepustowości wszystkich punktów wejścia. Wyłączone z realizacji tego obowiązku są również te podmioty, które dostarczają gaz ziemny z zagranicy, nie wykorzystując w tym celu krajowego systemu przesyłowego, tylko na przykład system dystrybucyjny lub gazociągi bezpośrednie.

Nie podlegają zwolnieniu z tego obowiązku przedsiębiorstwa energetyczne zajmujące się obrotem gazem ziemnym z zagranicą wchodzące w skład grupy kapitałowej ${ }^{10}$, jeżeli łączna wielkość przepustowości w punktach wejścia do krajowego systemu przesyłowego, do których przedsiębiorstwo to ma prawo, jest większa niż $10 \%$ sumy przepustowości wszystkich punktów wejścia. Oznacza to, że obowiązek wypełniania obliga giełdowego nałożony jest na wszystkich przedsiębiorców, którzy są kontrolowani w rozumieniu tej ustawy w sposób bezpośredni lub pośredni przez jednego przedsiębiorcę.

Brak wypełnienia tego obowiązku przez podmioty zobowiązane skutkuje nałożeniem na przedsiębiorstwo kary pieniężnej w wysokości do 15\% rocznego przychodu przedsiębiorstwa $\mathrm{z}$ działalności objętej koncesją, wymierzanej na podstawie decyzji Prezesa Urzędu Regulacji Energetyki (URE), zgodnie z art. 56 pkt 32 ustawy PE.

Zgodnie $\mathrm{z}$ uzasadnieniem do projektu ustawy ${ }^{11}$ wprowadzony obowiązek ma prowadzić do utworzenia hurtowego rynku gazu ziemnego, gdzie podmioty sprowadzające gaz ziemny z zagranicy oraz wydobywające go ze złóż krajowych będą go oferowały wszystkim zainteresowanym podmiotom na niedyskryminacyjnych zasadach. Dzięki udostępnieniu gazu na giełdach towarowych odbiorcy będą mieli możliwość skorzystania z prawa do zmiany sprzedawcy, zagwarantowanego w art. 4j ust. 1 ustawy PE. Jednocześnie odbiorca, który nie będzie korzystał z prawa do zmiany sprzedawcy, będzie mógł być obsługiwany przez dotychczasowego dostawcę. Dodatkowo, biorąc pod uwagę potrzebę promowania zmiany struktury rynku gazu, z przedmiotowego obowiązku zwolniono podmioty, które sprowadzają gaz ziemny do Polski w niewielkiej skali, to jest mają prawo do przepustowości w punktach wejścia w wielkości mniejszej niż $10 \%$ sumy przepustowości wszystkich tych punktów.

Tak ukształtowany obowiązek prawny rodzi wiele wątpliwości natury prawnej i ekonomicznej. Od strony prawnej dotyczą one kompletności prawnej tych rozwiązań oraz ich zgodności z Konstytucją RP. Od strony ekonomicznej zaś dotyczą one zasadności zastosowanego modelu regulacji w kontekście istniejącej struktury rynku krajowego i rynku Unii Europejskiej oraz kierunków ich zmian.

i gazu ziemnego oraz zasadach postępowania w sytuacjach zagrożenia bezpieczeństwa paliwowego państwa i zakłóceń na rynku naftowym (Dz. U 2012 poz. 1190).

$10 \mathrm{~W}$ rozumieniu art. 4 pkt. 14 ustawy z 16 lutego 2007 r. o ochronie konkurencji i konsumentów (Dz. U $2007 \mathrm{nr} 50$ poz. 331).

11 Poselski projekt ustawy o zmianie ustawy - Prawo energetyczne oraz niektórych innych ustaw, druk nr 946, www.sejm.gov.pl. 


\section{UWARUNKOWANIA GOSPODARCZE}

Polska zużywa rocznie około $15,4 \mathrm{mld} \mathrm{m}^{3}$ gazu ziemnego $(2012 \mathrm{r} \text {. })^{12}$, co plasuje ją jako 8 największego konsumenta w UE. Równocześnie jest ona silnie uzależniona od dostaw tego towaru z zagranicy. Import i nabycie wewnątrzwspólnotowe gazu ziemnego stanowią 74\% konsumowanego towaru. Dodatkowo, Polska nie ma zdywersyfikowanej struktury dostaw gazu ziemnego, gdyż 79,6\% wolumenu dostaw gazu z zagranicy pochodzi z Rosji, co oznacza, że kraj ten dostarcza 58\% konsumowanego w Polsce gazu ziemnego ${ }^{13}$.

Taka struktura rynku jest specyficzna na tle innych państw członkowskich UE. Z jednej strony poziom zależności od importu gazu ziemnego z zagranicy jest korzystny dla Polski, gdyż większość innych państw członkowskich UE jest w większym zakresie zależna od dostaw z zagranicy. W korzystniejszej sytuacji są tylko państwa eksporterzy (Holandia i Dania) oraz Rumunia (rys. 1).

Rys. 1. Poziom zależności od importu gazu państw europejskich w 2010 r.

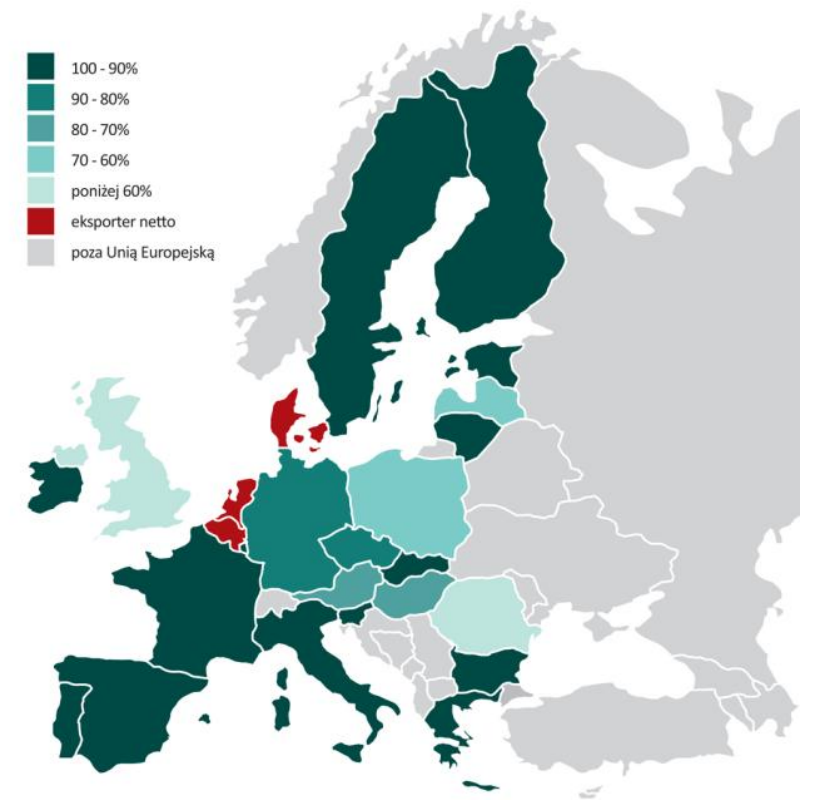

Źródło: opracowanie własne na podstawie Eurostat.

Ważna jest jednak również struktura dostaw z zagranicy, czyli zależność od jednego lub kilku kierunków i źródeł dostaw gazu ziemnego. Jak wynika z rysunku 2, różna jest charakterystyka państw członkowskich UE w tym zakresie. Niecała połowa państw ma co najmniej trzy kierunki dostaw. Wśród tych, które mają jeden lub dwa, znacząca jest produkcja krajowa (Rumunia, Chorwacja, Wielka Brytania). Przeważają jednak państwa, które mają co najmniej dwa źródła i kierunki dostaw. Na tym tle poziom dywersyfikacji

12 Dane Polskiego Górnictwa Naftowego i Gazownictwa (PGNiG).

13 Odbywa się to $\mathrm{w}$ ramach długoterminowego kontraktu na zakup gazu z Rosji, tak zwanego kontraktu jamalskiego. 
Polski jest mniej korzystny niż większości innych państw Unii Europejskiej.

Rys. 2. Poziom dywersyfikacji źródeł i kierunków dostaw w UE

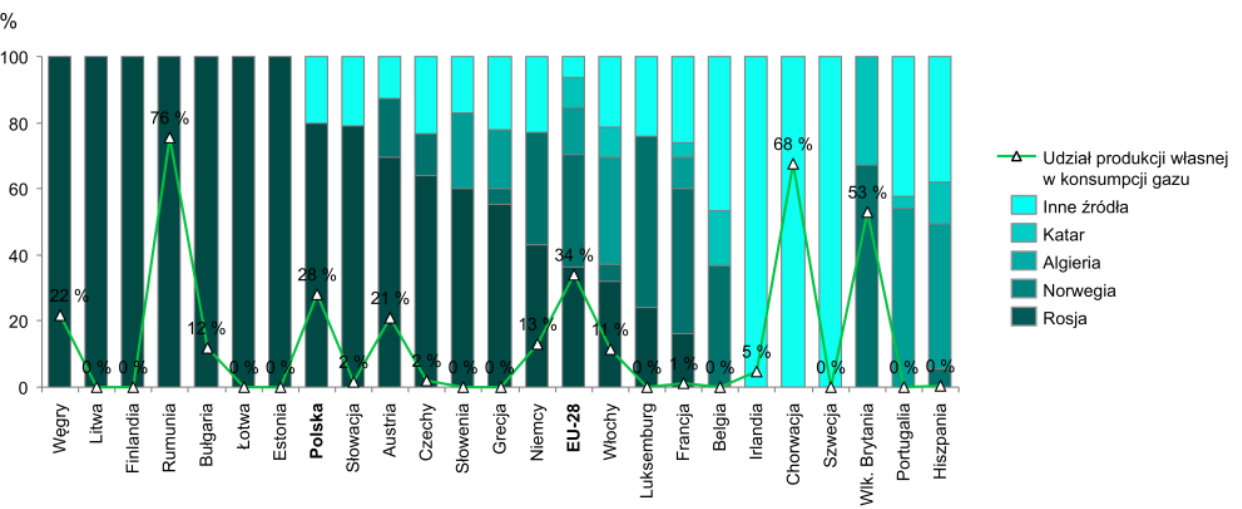

Źródło: opracowanie własne na podstawie danych Eurogas.

Działania podejmowane $\mathrm{w}$ tym zakresie przez Polskę mają na celu zmianę takiego modelu zależności. Dokumentem programowym w tym obszarze jest między inymi Polityka energetyczna Polski do $2030 \quad r$., w której dąży się do zapewnienia bezpieczeństwa energetycznego kraju, zakładając konieczność dywersyfikacji ${ }^{14}$. Cel ten ma być osiągnięty poprzez zwiększenie poziomu wydobycia krajowego gazu ziemnego (zarówno ze źródeł konwencjonalnych, jak i niekonwencjonalnych), co ma podwyższyć poziom samowystarczalności, rozwój alternatywnych źródeł i kierunków dostaw, między innymi poprzez inwestycje w terminal LNG w Świnoujściu, rozbudowę połączeń wzajemnych (interkonektorów) z innymi państwami członkowskimi Unii Europejskiej (zarówno poprzez tworzenie nowych połączeń, rozbudowę istniejących, jak i umożliwienie tak zwanego fizycznego rewersu na połączeniach, na których rewers miał dotychczas charakter wirtualny). W zakresie regulacyjnym wprowadzono między innymi wymagania prawne co do maksymalnego udziału gazu ziemnego importowanego $\mathrm{z}$ jednego kraju pochodzenia $\mathrm{w}$ stosunku do całkowitej wielkości gazu importowanego $\mathrm{w}$ danym roku ${ }^{15}$. Poziom ten nie może być wyższy w 2014 r. niż 70\%, a w latach 2015-2020 - 59\%, w latach 2019-2020 zaś ma osiągnąć poziom 49\%. Oznacza to konieczność podjęcia działań przez importera w kierunku dywersyfikacji źródeł dostaw gazu ziemnego. Zgodnie $\mathrm{z}$ tą regulacją nie dotyczy ona gazu ziemnego wydobywanego $\mathrm{w}$ państwach członkowskich UE. Celem ustawodawcy było zatem wymuszenie dywersyfikacji dostaw gazu na poziomie faktycznego pozyskania surowca, a nie jedynie państwa jego umownego nabycia. Mimo że taki zakres obowiązków nałożony na podmiot dostarczający gaz do Polski rodzi określonego rodzaju trudności, związane między innymi z udowodnieniem źródła pochodzenia gazu ziemnego, co może być trudne, na przykład w sytuacji nabycia go na giełdzie za granicą, stanowi to o intencji ustawodawcy do

14 Załącznik do Uchwały nr 202/2009 Rady Ministrów z 10 listopada 2009 r. Polityka energetyczna Polski do 2030 r., s. 11-12.

15 Rozporządzenia Rady Ministrów z 24 października 2000 r. w sprawie minimalnego poziomu dywersyfikacji dostaw gazu z zagranicy, gdyż wpływa ono również na kierunki dywersyfikacji (Dz. U $2000 \mathrm{nr} 95$ poz. 1042). 
zapewnienia większej dywersyfikacji źródeł i kierunków dostaw.

Oprócz źródeł i kierunków pozyskania gazu ziemnego, ważna jest również struktura jego sprzedaży w kraju. Rynek sprzedaży hurtowej gazu w 2012 r. był zdominowany przez jeden podmiot, spółkę PGNiG, która miała około $96 \%$ udziału w rynku ${ }^{16}$. Podobnie na rynku detalicznym, gdzie w $2012 \mathrm{r}$. PGNiG miało udział w rynku w wysokości prawie $95 \%{ }^{17}$. Pozostały obrót gazem był rozproszony między wiele małych, konkurujących ze sobą spółek gazowych ${ }^{18}$. Charakterystyka ta ma znaczenie dla zaproponowanego modelu regulacyjnego obliga giełdowego.

Dotychczasowy model obrotu hurtowego i detalicznego w Polsce oparty był przede wszystkim na umowach dwustronnych z odbiorcami, gdzie obrót giełdowy stanowił niewielki fragment rynku. Zobowiązania umowne z kontraktów importowych (kontrakt jamalski i w przyszłości kontrakt katarski) były i mogły być przenoszone na odbiorców z rynku hurtowego lub detalicznego. Nowy model rynku ingeruje $w$ te zobowiązania umowne, przenosząc te ryzyka i koszty na rynek giełdowy.

Rys. 3. Porównanie rynku hurtowego w wybranych państwach UE w 2013 r.

UDZIAL RYNKU GIEtDOWEGO W OBROCIE GAZEM NA WYBRANYCH RYNKACH UNII EUROPEJSKIEJ W 2013 R.

100

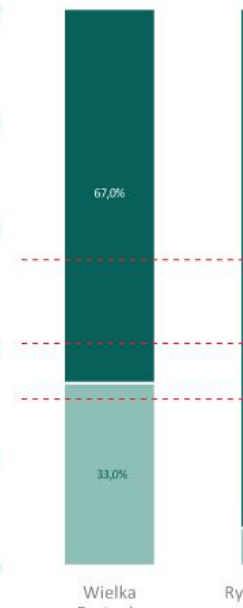

Wielka
Brytania

2 hubem TTF
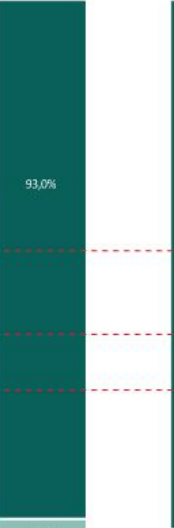
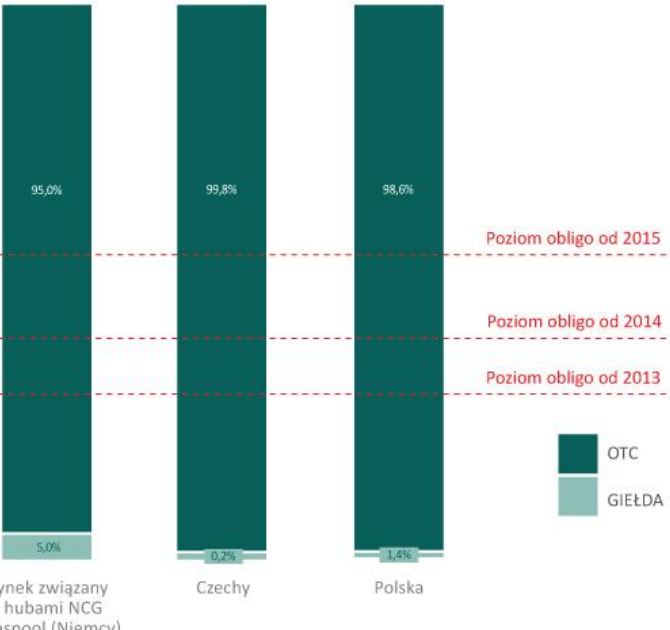

Wvmogi obligo gazowego w Polsce znacznie powvżei udziału giełd na rvnkach zachodniei Europv

Źródło: R. Zajdler, Polski rynek hurtowy gazu ziemnego na tle rynków Unii Europejskiej, Warszawa 2014, s. 33.

Taki model obrotu na rynku hurtowym jest odmienny od obserwowanego w innych

16 Raport Krajowy Prezesa Urzędu Regulacji Energetyki za 2013 r., Warszawa lipiec 2013 r., www.ure.gov.pl/download/1/6634/Raport2013.pdf, s. 65 (dostęp: 29.05.2014).

17 Ibidem, s. 65. Należy jednak zauważyć, że ta statystyka nie uwzględnia zakupu dokonywanego przez samych odbiorców końcowych poza granicami Polski i sprowadzania gazu ziemnego na potrzeby własne. Skala tego zjawiska może zmniejszać znacząco udział PGNiG w rynku detalicznym gazu. Brak jednak w tym zakresie danych statystycznych.

18 Taka struktura rynku nie uległa znaczącym zmianom w kolejnych latach. Szerzej: R. Zajdler, Polski rynek, Warszawa 2014, s. 22. 
państwach członkowskich Unii Europejskiej. Tam obrót hurtowy odbywa się w przeważającej mierze w ramach umów bilateralnych (OTC, over-the-counter), w których strony ustalają warunki łączącej je umowy dostawy. Obrót giełdowy, to jest w ramach transakcji anonimowych i o zestandaryzowanej charakterystyce, odbywających się za pośrednictwem giełdy, stanowi znacząco mniejszy wolumen obrotu.

Przewaga umów bilateralnych nad obrotem giełdowym w UE wynika z istotnej charakterystyki tych instrumentów i związanych z tym możliwości dostosowania ich do potrzeb rynku. Umowy bilateralne dają możliwość ustalenia ich warunków indywidualnie przez strony umowy, szczególnie wyceny paliwa na podstawie wynegocjowanej formuły cenowej. Zmniejsza to ryzyko, dając szansę na wprowadzenie zapisów zwiększających elastyczność umowy oraz na przykład dostosowanie dostaw do własnego cyklu produkcyjnego odbiorcy. Rynek giełdowy jest najprawdopodobniej lepszą platformą dla obrotu międzynarodowego poprzez funkcjonowanie na nim tak zwanych aukcji implicit, na których kupuje się zarówno gaz ziemny, jak i zdolność przesyłową. Obrót zestandaryzowanymi produktami daje większe pole do zysku spekulacyjnego. Duża oferta różnorodnych produktów giełdowych może zaspokoić oczekiwania rynku, wymaga jednak budowania własnej pozycji poprzez różne instrumenty giełdowe, co może zwiększać ryzyko i koszty. Dlatego też obrót giełdowy na rynkach UE stanowi raczej uzupełnienie pozycji kontraktowych niż główny mechanizm obrotu ${ }^{19}$.

Widać to wyraźnie na przykładach kilku państw UE, które mają znacząco rozwinięte rynki hurtowe gazu ziemnego. W Niemczech, gdzie trzy największe spółki odpowiadają zaledwie za $28,5 \%{ }^{20}(2012$ r.) dostaw gazu dla odbiorcy końcowego, obrót giełdowy wynosi zaledwie 5\% (2013 r.) krajowego obrotu gazem. W Holandii udział ten wyniósł w 2013 r. jedynie 7\%. Pozostałe umowy w tych dwóch państwach realizowane są na podstawie kontraktów OTC, których wolumen niejednokrotnie znacznie przewyższa krajową konsumpcję. Niektóre rynki krajowe państw UE opierają się niemal wyłącznie na tych kontraktach, czego przykładem jest Hiszpania, gdzie ich wolumen przewyższa krajową konsumpcję o $25 \%$, a udział trzech największych przedsiębiorstw wynosi zaledwie 47\%. Podobnie funkcjonują rynki Europy Środkowo-Wschodniej. W Czechach udział największej spółki wyniósł 41,5\%, a trzy największe przedsiębiorstwa dostarczały $56 \%$ gazu $^{21}$. Udział obrotu giełdowego na rynku brytyjskim wyniósł 33\% w 2013 r., ale rynek ten charakteryzuje się wysokim udziałem produkcji własnej oraz dużą dywersyfikacją źródeł i kierunków dostaw.

Poziom obliga giełdowego w Polsce na sztywnym poziomie 40\% w 2014 r. i 55\% w latach następnych jest znacząco wyższy od nawet tak rozwiniętego rynku hurtowego jak rynek brytyjski. Dodatkowo, Polska nie ma tak zdywersyfikowanej struktury dostaw gazu ziemnego jak Wielka Brytania, która otrzymuje gaz ziemny zarówno poprzez gazociągi importowe $\mathrm{z}$ Norwegii, dostawy wewnątrzwspólnotowe $\mathrm{z}$ UE, terminale LNG umożliwiające dostawy $z$ innych państw na świecie i przez wydobycie krajowe. Rynek Polski jest zamknięty i zdominowany przez jeden podmiot, co czyni poziom obliga giełdowego na zaproponowanym poziomie sztucznym ${ }^{22}$.

19 Szerzej R. Zajdler, Polski rynek..., s. 33-41.

20 Brak danych za $2013 \mathrm{r}$.

21 Analiza własna na podstawie BP Statistical Review 2013.

22 R. Zajdler Polski rynek..., s. 33-41; Szerzej: idem, Pespektywy rozwoju formul cenowych w kontraktach dtugoterminowych na dostawy gazu ziemnego oraz ich znaczenie dla stworzenia w 
Odmienność modelu rynku hurtowego w Polsce i w innych państwach Unii Europejskiej widoczna jest również w tempie wprowadzania tych zmian. Od powstania dzisiejszej UE podejmowane były działania mające na celu zwiększenie wpływu samej Unii na rozwój krajowych rynków gazu ziemnego. Dążenia państw członkowskich do samodzielnego decydowania o kierunkach rozwoju tego sektora sprawiły, że do końca lat dziewięćdziesiątych XX w. brakowało jednolitych reguł prawnych dotyczących liberalizacji rynku gazu i wprowadzenia na nim zasad konkurencji. Działania regulacyjne dzisiejszej UE koncentrowały się na zwiększeniu wpływu na regulacje krajowe dotyczące - poprzez wzmocnienie polityki ochrony środowiska, polityki konkurencji - regulacji w zakresie bezpieczeństwa dostaw czy też swobód rynku wewnętrznego. Podstawy do budowania jednolitego rynku gazu ziemnego dały dopiero uregulowania od lat dziewięćdziesiątych XX w., które wprowadziły pierwszy pakiet liberalizacyjny rynku gazu ziemnego ${ }^{23}$. Istotny rozwój tego rynku to jednak uregulowania wprowadzone $w$ 2009 r., tworzące tak zwany trzeci pakiet liberalizacyjny ${ }^{24}$. Mimo tych uwarunkowań, proces budowania hurtowego rynku gazu ziemnego w państwach UE trwał ponad dwie dekady. Był on wynikiem współpracy instytucji regulujących rynek z przedsiębiorstwami na nim działającymi dążącej do tego, aby wprowadzanie nowych mechanizmów nie generowało powstania tak zwanych kosztów osieroconych. Zmiany miały na celu ewolucyjne dochodzenie do nowego modelu rynku.

Regulacja art. 49b ustawy PE, wprowadzająca obligo giełdowe na rynku gazu ziemnego, wpisuje się $\mathrm{w}$ działania regulacyjne mające na celu zmianę struktury krajowego rynku gazu ziemnego i zwiększenia na nim poziomu konkurencji. Konieczność dokonywania takich działań wynika $\mathrm{z}$ implementacji regulacji prawa UE dotyczących liberalizacji rynku gazu ziemnego oraz likwidacji taryf dla odbiorców końcowych. Mają one na celu integrację $w$ ramach powiązań regionalnych, a docelowo stworzenie jednolitego rynku gazu w Unii Europejskiej ${ }^{25}$. Rynek taki ma dawać odpowiednie sygnały cenowe i popytowe, a tym samym wpływać na kształt rynku detalicznego. Cel ten jest jednak osiągany $\mathrm{w}$ różny sposób przez poszczególne państwa członkowskie. Najczęstszym rozwiązaniem jest dążenie do połączenia rynków krajowych w rynek regionalny, zarówno poprzez inwestycje $\mathrm{w}$ infrastrukturę, jak i zapewnienie funkcjonowania giełd gazu o zasięgu szerszym niż krajowy ${ }^{26}$. Giełdy gazu tworzą natomiast cenę referencyjną gazu ziemnego oraz zapewniają ofertę produktową dostosowaną do potrzeb rynku. Znoszone są regulacje administracyjnie w kierunku

Polsce hubu gazowego dla państw Europy Środkowo-Wschodniej, Warszawa 2012, s. 76-101.

23 Dyrektywa Parlamentu Europejskiego i Rady 98/30/WE z 22 czerwca 1998 r. dotyczaca wspólnych zasad w odniesieniu do rynku wewnętrznego gazu ziemnego (Dz. U L 204 z 21/07/1998, s. 1-12).

24 W zakresie liberalizacji rynku gazu ziemnego znaczenie mają: dyrektywa Parlamentu Europejskiego i Rady 2009/73/WE z 13 lipca 2009 r. dotycząca wspólnych zasad rynku wewnętrznego gazu ziemnego i uchylająca dyrektywe 2003/55/WE (Dz. U L 211 z 14/08/2009, s. 94-136), rozporządzenie Parlamentu Europejskiego i Rady (WE) nr 715/2009 z 13 lipca 2009 r. w sprawie warunków dostępu do sieci przesyłowych gazu ziemnego i uchylające rozporządzenie (WE) nr 1775/2005 (Dz. U L 211 z 14/08/2009, s. 36-54).

25 R. Zajdler, Legal Aspects of Electricity and Gas Interconnectors with Third Countries, [w:] EU Energy Law, Legal constraints with the implementation of Third Liberalisation Package, red. Robert Zajdler[Cambridge 2012, s. 157.

26 R. Zajdler, Polski rynek hurtowy..., s. 32. 
wzmocnienia mechanizmów rynkowych. W tym kontekście zmiana wprowadzona w regulacjach prawa krajowego nie jest dostosowana do funkcjonującego już w innych państwach UE modelu hurtowego rynku gazu ziemnego, gdzie obrót hurtowy odbywa się przede wszystkim w ramach umów dwustronnych, a giełda stanowi uzupełnienie rynku. Jeśli wziąć pod uwagę liczbę podmiotów zobowiązanych, tworzona przez rynek cena giełdowa może nie być uznana przez rynek za cenę referencyjną.

\section{DOPUSZCZALNOŚCI NALOŻENIA OBOWIAZZKU}

Zgodnie z art. 487 § 2 k.c. ${ }^{27}$ sprzedaż jest umową konsensualną, odpłatną, wzajemną. Jest ona również umową zobowiązującą, choć może wywoływać równocześnie skutki rozporządzające (art. 155 k.c., 510 k.c., 1052 k.c.) ${ }^{28}$. Z taką też umową mamy do czynienia $\mathrm{w}$ art. 49b ustawy PE. Odnosząc zatem te wymagania ustawy kodeksu cywilnego do regulacji art. 49b ustawy PE, należy zauważyć, że zawarcie tej umowy wymaga zgodnej woli obu stron umowy - sprzedającego i kupującego. To zaś oznacza, że nałożenie na jeden podmiot, tak jak w art. 49b ust. 1 ustawy PE, obowiązku zawarcia umowy sprzedaży poprzez giełdę stoi w sprzeczności z samą istotą sprzedaży. Konkluzja ta oznacza, że nie jest możliwe nałożenie obowiązku zawarcia umowy sprzedaży tylko na jeden z podmiotów, nawet na rynku częściowo regulowanym. Prawne, jak i faktyczne uzasadnienie mogłoby znaleźć wprowadzenie obowiązku złożenia oferty sprzedaży o określonym kształcie i w sprecyzowanych warunkach. Oferta taka odpowiadałaby jednak wymaganiom art $66 \mathrm{i}$ n. k.c. W analizowanym stanie prawnym ustawodawca zobowiązał sprzedającego w praktyce do znalezienia kupującego na oferowany przez niego towar. Nałożenie takiego obowiązku na sprzedającego do poniesienia ryzyka związanego ze znalezieniem kupującego nie ma uzasadnienia prawnego.

W prawie cywilnym dopuszczalne są sytuacje, w których orzeczenie sądu zastępuje złożenie oświadczenia przez jedną ze stron umowy, na przykład umowy sprzedaży. Dotyczy to jednak sytuacji, w których strony zawarły już umowę przedwstępną o określonej treści i formie, co oznaczało wolę zawarcia umowy. Wówczas pierwszym krokiem było wyrażenie przez obie strony woli zawarcia umowy sprzedaży. Co więcej, mowa tu o obowiązku złożenia oświadczenia woli o określonej treści, a nie zawarciu samej umowy. Zatem złożenie oświadczenia woli może być przedmiotem obowiązku prawnego, który może wynikać z różnych wcześniej zaistniałych zdarzeń prawnych (źródeł obowiązku złożenia oświadczenia woli), z których najważniejszym jest umowa przedwstępna, umowa zobowiązująca do dokonania rozporządzenia (art. 155 k.c. i art. 510 k.c.), przyrzeczenie publiczne (art. 919 k.c.). Zastępowanie oświadczenia woli jednej ze stron umowy decyzją właściwego organu sądowego odbywa się zatem w sytuacji istnienia domniemania woli zawarcia umowy ostatecznej. Taka sytuacja nie zachodzi jednak w analizowanej regulacji art. 49b ustawy PE, gdyż kupujacy gaz ziemny ma pełną swobodę dokonania zakupu zarówno na giełdzie, jak i poza nią.

Również regulacje prawa administracyjnego dopuszczają wydanie decyzji kształtującej stosunek umowny miedzy stronami. Zgodnie $\mathrm{z}$ art. 8 ust. 1 ustawy PE w sprawach spornych dotyczących odmowy zawarcia wymienionych enumeratywnie umów zawieranych na rynku energii, takich jak umowy o przyłączenie do sieci, umowy

\footnotetext{
${ }^{27}$ Ustawa z 23 kwietnia 1964 r. Kodeks cywilny (Dz. U 2014 nr 121 jt.).

28 Por. G. Bieniek, Ciepła H., Dmowski S. i in., Komentarz do kodeksu cywilnego. Ksiega trzecia. Zobowiązania, Warszawa 2011
} 
sprzedaży czy też umowy kompleksowe, rozstrzyga Prezes URE na wniosek strony. Pozwala to Prezesowi URE ukształtować stosunek umowny w wyniku decyzji administracyjnej. Wymagane jest jednak wcześniejsze współdziałanie obu stron, czyli wola zawarcia umowy, niemożność uzgodnienia jej warunków oraz wniosek jednej z nich o rozstrzygnięcie sporu. Odbywa się to jednak w ramach umów zawieranych na rynku regulowanym i kontrolowanym przez Prezesa URE, który zgodnie z art. 23 ust. 1 ustawy PE ma za zadanie równoważenie interesów przedsiębiorstw energetycznych i odbiorców paliw i energii. Dodatkowo od decyzji Prezesa URE jest możliwość odwołania do sądu powszechnego.

Nałożenie obowiązku, o którym mowa w art. 49b ustawy PE, stanowić może od strony prawnej obowiązek niemożliwy do wykonania. Niemożność wykonania polega zarówno na obowiązku znalezienia kupującego, który zgodzi się nabyć gaz ziemny za pośrednictwem giełdy, ponosząc wynikające $\mathrm{z}$ tego ryzyko, koszty i opłaty. Obowiązek taki nie wynika $\mathrm{z}$ cywilistycznej konstrukcji umowy sprzedaży. W tym zaś zakresie zarówno sądy powszechne i administracyjne, jak i sam Trybunał Konstytucyjny wielokrotnie zajmowały stanowisko, zgodnie z którym nakładanie takich obowiązków przez ustawodawcę jest co najmniej niedopuszczalne $\mathrm{i}$ niezgodne $\mathrm{z}$ obowiązującą Konstytucją RP.

Ustawodawca na etapie tworzenia prawa nie może nakładać takiego obowiązku ${ }^{29}$. Jak zauważył Trybunał Konstytucyjny (wyrok z 13 marca 2007 r., sygn. akt K8/07): „[...] należy zaznaczyć, że ustawodawca nie może nakładać na adresatów prawa obowiązków niemożliwych do wykonania. Zasada impossibile nulla obligatio est powinna być także dla ustawodawcy ważną dyrektywą w procesie stanowienia prawa”.

Również wykładnia prawa na etapie jego stosowania nie może prowadzić do nałożenia na podmiot obowiązków niemożliwych do wykonania ${ }^{30}$. W wyrokach Naczelnego Sądu Administracyjnego (NSA) wyrażona jest teza, że nie można dokonywać wykładni prawa, której rezultat prowadziłby do nałożenia na podmiot obowiązków niemożliwych do wykonania $^{31}$. Takie działanie prowadzi wprost do naruszenia wyrażonej w art. 2 Konstytucji zasady zaufania do państwa i prawa. Prawo nie może, zgodnie z zasadą impossibilium nulla obligatio, nakładać na obywateli obowiązków niemożliwych do spełnienia. Trybunał Konstytucyjny w swym orzecznictwie przyjął, że nie ogranicza on zakresu oddziaływania zasady ochrony zaufania wyłącznie do procesu stanowienia prawa, gdyż wyraźnie akcentuje potrzebę ochrony zaufania obywateli również w procesie stosowania prawa. Trybunał Konstytucyjny ustalił, że ochronie konstytucyjnej podlega nie tylko zaufanie obywateli ,[...] do litery prawa, ale przede wszystkim do sposobu jego interpretacji przyjmowanej w praktyce stosowania prawa przez organy państwa" ${ }^{32}$.

Stanowienie i stosowanie prawa nie może być bowiem pułapką dla obywateli ${ }^{33}$. Takie bowiem normy prawne stanowić mogą naruszenie konstytucyjnej zasady zaufania

29 Wyrok Trybunału Konstytucyjnego z 13 marca 2007 r., sygn. akt K8/07.

30 Wyrok Naczelnego Sądu Administracyjnego z 23 kwietnia 2013 r., sygn. akt II GSK 51/2012.

31 Por. wyrok NSA z 23 kwietnia 2013 r., sygn. akt II GSK 51/2012.

32 Por. E. Morawska, Klauzula państwa prawnego w Konstytucji RP na tle orzecznictwa Trybunatu Konstytucyjnego, Dom Organizatora, Toruń 2003, s. 349. Także wyroki TK z 27 listopada 2007 r. U. 11/97, OTK ZU Nr 5-6 (14-15)/1997, s. 475 oraz z 9 października 2001 r. SK 8/2000, OTK ZU $\mathrm{Nr} 7$ (45)/2001, s. 1035.

33 Wyrok Trybunału Konstytucyjnego z 29 listopada 2006 r.; sygn. akt SK 51/06. 
obywateli do państwa i prawa. Nie mogą zatem ani organy administracji, ani sądy dokonywać wykładni przepisów prawa, która prowadziłaby do nałożenia obowiązków niemożliwych do wykonania. Takim obowiązkiem niemożliwym do wykonania mogłoby być w praktyce wykonanie obliga giełdowego na poziomie 30\% w 2013 r. ze względu na to, że regulacje umożliwiające $\mathrm{w}$ praktyce obrót gazem ziemnym na giełdzie wprowadzono dopiero w grudniu 2013 r. Sprzedający miał niewiele czasu na spełnienie wolumenowo obowiązku przypadającego na okres od wejścia w życie ustawy (11 września 2013 r.) aż do końca 2013 r. Biorąc pod uwagę skalę obowiązku, krótki okres realizacji, konieczność uregulowania w odmienny sposób od dotychczasowych umów dostawy, regulacja ta budzi wątpliwości konstytucyjne.

Na tym tle powstaje wątpliwość co do zakresu uprawnień Prezesa URE. Gdyby doszło do nałożenia kary na sprzedawcę $\mathrm{z}$ tytułu braku realizacji obowiązku, istotne będą argumenty mogące podważyć nie tyle brzmienie samego przepisu, ale prawidłowość dokonanej przez Prezesa URE wykładni i zastosowanie omawianej normy. Literalne brzmienie art. 49 b ust. 1 ustawy PE jak i art. 56 ust. 1 pkt 32 ustawy PE wskazuje na obligatoryjny charakter kary, jaką Prezes URE zobowiązany jest nałożyć na przedsiębiorcę, który obiektywnie nie wywiązał się $\mathrm{z}$ obliga giełdowego. Odpowiedzialność na podstawie tej normy ma charakter obiektywny i nie jest konieczne wykazanie umyślnej albo nieumyślnej winy ukaranego podmiotu ${ }^{34}$. Oznaczałoby to, że nawet przy uznaniu wadliwości powołanych przepisów Prezes URE, nakładając karę, nie dopuszcza się naruszenia jakichkolwiek przepisów, gdyż realizuje nałożony na niego obowiązek ustawowy. Prezes URE ma możliwość nienałożenia kary albo jej odpowiedniego miarkowania w ramach okoliczności konkretnej sprawy.

\section{ZASADY LICZENIA PRZEPUSTOWOŚCI}

Zgodnie $\mathrm{z}$ art. 49b ust. 3 ustawy PE obligo giełdowe zostało nałożone jedynie na tych uczestników rynku, którzy mają $\mathrm{w}$ danym roku prawo do przepustowości na punktach wejścia do krajowego systemu przesyłowego w wielkości nie mniejszej niż $10 \%$ całkowitej wielkości przepustowości wszystkich punktów wejścia. Ratio legis tego wyłączenia, zgodnie z uzasadnieniem do projektu ustawy, to ,potrzeba promowania zmian struktury rynku gazu”. Zatem z przedmiotowego obowiązku zwolniono „podmioty, które sprowadzają gaz ziemny do Polski w niewielkiej skali”. Za taką niewielką skalę uznano posiadanie prawa do przepustowości w wielkości mniejszej niż $10 \%$ sumy przepustowości wszystkich tych punktów ${ }^{35}$.

$\mathrm{Na}$ wstępie należałoby zdefiniować, o jaką przepustowość chodzi ustawodawcy. Zgodnie z Instrukcją Ruchu i Eksploatacji Sieci Przesyłowej spółki Gaz-System (dalej: IRIESP $^{36}$, operatora systemu przesyłowego, zdefiniowanych jest kilka rodzajów przepustowości: techniczna, umowna, warunkowa czy też zarezerwowana. Największa nominalnie jest przepustowość techniczna, definiowana jako maksymalna ciągła przepustowość systemu przesyłowego, w której ramach operator systemu przesyłowego

34 Por. wyrok Sądu Najwyższego z 1 czerwca 2010 r., sygn. akt III SK 5/2010, czy wyrok Sądu Apelacyjnego w Warszawie z 10 października 2012 r., sygn. akt VI ACa 398/2012.

35 Poselski projekt ustawy o zmianie ustawy - Prawo energetyczne oraz niektórych innych ustaw, druk nr 946, www.sejm.gov.pl.

36 Wersja nr 023 z listopada 2013 r., www.gaz-system.pl. Podobne rozwiązania są również w IRIESP dotyczącym funkcjonowania SGT Jamał. 
może świadczyć usługi przesyłania paliwa gazowego. Przez przepustowość umowną zaś rozumie się określoną na podstawie umowy przesyłowej przepustowość, do której uprawniony jest użytkownik systemu ${ }^{37}$. Przepustowość warunkowa to taka, która jest udzielana na zasadach ciągłych użytkownikowi systemu w fizycznym punkcie wyjścia, pod warunkiem uzyskania przez niego odpowiedniego przydziału przepustowości na zasadach ciągłych w fizycznym punkcie wejścia, z którego zasilanie jest niezbędne dla zapewnienia dostarczania paliwa gazowego do danego fizycznego punktu wyjścia. Natomiast przepustowość zarezerwowana to taka część technicznej przepustowości systemu przesyłowego, która jest zarezerwowana przez operatora tego systemu w związku z podpisanymi umowami.

Ustawodawca nie zdefiniował w art. 49b ust. 3 ustawy PE, o jaką przepustowość chodzi. Punktem odniesienia może być zarówno przepustowość techniczna, umowna, jak i zarezerwowana. Przepustowość techniczna oznacza całkowite możliwości danego połączenia. Zarówno przepustowość umowna, jak i zarezerwowana są częścią tej przepustowości. Wydaje się, że podstawą obliczenia powinna być taka wielkość przepustowości, która jest udostępniana rynkowi na cele handlowe, zatem powinna to być przepustowość umowna.

Podobnie brak jasności, jak liczyć posiadaną przez przedsiębiorstwo zobowiązane przepustowość. W tym wypadku powinna być brana pod uwage również przepustowość umowna. Świadczyć o tym może pkt 7.4 IRIESP, zgodnie z którym „o udostępnienie przepustowości może się ubiegać jedynie Użytkownik Systemu, z którym została zawarta umowa przesyłowa. Załącznikiem do umowy przesyłowej są przydziały przepustowości i zdolności (PP/PZ) zawierane w formie pisemnej, lub w formie elektronicznej”. Oznacza to, że podstawą rozliczeń między użytkownikiem systemu a operatorem systemu przesyłowego jest umowa określająca przydziały przepustowości. Również literalne brzmienie przepisu art. 49b ustawy PE zakłada, że nie ma znaczenia faktyczne wykorzystanie tej przepustowości, a jedynie zarezerwowane prawo do przepustowości.

Przepustowość umowna jest przydzielana w różnym zakresie zainteresowanym podmiotom. Zgodnie z punktem 7.1.11 IRIESP przepustowość jest przydzielana przez operatora systemu przesyłowego na okresy: roczne, kwartalne, miesięczne, jednej doby gazowej. Jest ona przydzielana odrębnie dla: przepustowości na zasadach ciągłych, przepustowości rewersowej na zasadach ciągłych, przepustowości warunkowej na zasadach ciągłych, przepustowości na zasadach przerywanych, przepustowości rewersowej na zasadach przerywanych. Przepis art. 49b ustawy PE nie ogranicza sposobu liczenia przepustowości, zatem należy przyjąć, że każdy z tych rodzajów przepustowości jest liczony na potrzeby tego przepisu w wartościach nominalnych. Nabycie w danym punkcie wejścia przepustowości na zasadach ciągłych przez podmiot, który miał wcześniej taką przepustowość na zasadach przerywanych, nie oznacza, że podmiot ten musi rezygnować $\mathrm{z}$ przepustowości na zasadach przerywanych (zob. pkt 7.2.3 IRIESP). Może to oznaczać, że taką samą fizyczną wielkość przepustowości będzie się liczyć podwójnie ze względu na sposób możliwego jej wykorzystania.

Przy obecnej strukturze rynku te wątpliwości nie mają większego praktycznego znaczenia, gdyż jest jeden podmiot - PGNiG S.A. - mający przepustowości w wielkości

37 Rozumianą jako maksymalna godzinowa ilość paliwa gazowego wyrażona w jednostkach objętości w warunkach normalnych, która może być przekazana do przesłania w fizycznym punkcie wejścia do systemu przesyłowego. 
przekraczającej 10\% sumy przepustowości punktów wejścia do krajowego systemu przesyłowego, niezależnie od sposobu jej kalkulacji. Jednakże w momencie osiągnięcia tego poziomu przez większą liczbę podmiotów takie rozróżnienie może mieć znaczenie, co może wymagać doprecyzowania tego przepisu.

\section{REGULACJE W ZAKRESIE TARYFOWANIA}

Na rynku konkurencyjnym oferenci zabiegają o klientów kilkoma determinantami, $\mathrm{W}$ tym ceną. Obecne regulacje prawa energetycznego nie pozwalają spółkom gazowym na swobodne ustalanie cen dla odbiorcy końcowego. Ceny gazu ziemnego zarówno dla przedsiębiorstw, jak i dla odbiorców socjalno-bytowych oparte są na taryfach, które muszą zostać zatwierdzone przez Prezesa URE.

Obecnie taryfy funkcjonują na wielu rynkach UE, ale nie obejmują one swoim zasięgiem wszystkich odbiorców, jak dzieje się to wciąż w Polsce. Najczęściej spotykane jest funkcjonowanie regulowanych cen dla gospodarstw domowych i dla małego biznesu. Istnieją jednak rynki, na których taryfy zostały całkowicie zniesione (z pominięciem taryf socjalnych dla odbiorców wrażliwych). Należą do nich w szczególności Niemcy i Czechy. Funkcjonowanie taryf dla przedsiębiorców jest rzadkością. Regulowane ceny dla przedsiębiorstw występują - oprócz Polski - jeszcze we Francji, Rumuni, Bułgarii i na Łotwie. Mają one jednak mniejsze znaczenie ${ }^{38}$. Taryfy zostały całkowicie zniesione między innymi w: Austrii, Belgii, Estonii, Finlandii, Holandii, Słowenii, Szwecji, we Włoszech czy w Wielkiej Brytanii.

Generalnie brak uwolnienia cen wiąże się z brakiem bodźca ekonomicznego dla rozwoju konkurencji po stronie podażowej rynku. Spółki oferujące gaz odbiorcom końcowym mają ograniczone możliwości zwiększania rentowności, a tym samym ograniczone jest ich zainteresowanie zwiększaniem ryzyka cenowego i kosztów zakupu gazu ziemnego. Zakup gazu na giełdzie łączy się $\mathrm{z}$ wieloma ryzykami, których nie ma $\mathrm{w}$ kontrakcie OTC. Brak możliwości ewentualnego przełożenia tych ryzyk na odbiorcę końcowego ogranicza skalę zainteresowania zakupem gazu ziemnego na giełdzie.

Znaczenie mają również regulacje prawne dotyczące zasad kształtowania taryf w obrocie gazem ziemnym. Zgodnie $\mathrm{z}$ art. 3 rozporządzenia taryfowego ${ }^{39}$ określone w taryfie ceny lub stawki opłat dla poszczególnych grup taryfowych różnicuje się odpowiednio do kosztów uzasadnionych wykonywanej działalności gospodarczej związanej $\mathrm{z}$ dostarczaniem paliw gazowych. Koszty, które mogą przeniesione na odbiorców końcowych w taryfie w zakresie obrotu paliwami gazowymi, dla kolejnego roku stanowią planowane koszty uzasadnione związane $\mathrm{z}$ tą działalnością oraz z marżą na uzasadnionym poziomie. Podstawą zaś ustalania i oceny kosztów są wielkości z roku poprzedniego. Podstawą ich oceny zaś mogą być porównywalne koszty działalności gospodarczej przedsiębiorstw energetycznych wykonujących - w porównywalnych warunkach - działalność gospodarczą tego samego rodzaju (art. 7 rozporządzenia taryfowego). Regulacja ta daje znaczącą uznaniowość Prezesowi URE w zakresie ustalenia, które koszty działalności w zakresie obrotu paliwami gazowymi uznaje za uzasadnione. Daje również możliwość ograniczania przenoszenia kosztów tej działalności na odbiorców końcowych w taryfie. Taka regulacja stanowi duże ryzyko dla

38 Na przykład we Francji wolumen ceny taryfowanej dla biznesu w 2012 r. wyniósł zaledwie 22\%. 39 Rozporządzenie Ministra Gospodarki z dna 28 czerwca 2013 r. w sprawie szczegółowych zasad kształtowania i kalkulacji taryf oraz rozliczeń w obrocie paliwami gazowymi (Dz. U $2013 \mathrm{nr}$ 820). 
przedsiębiorstwa energetycznego podejmującego ryzyko zakupu gazu ziemnego na giełdzie, gdyż dodatkowe koszty wynikające z takiego zakupu mogą nie być uznane przez Prezesa URE za uzasadnione, a tym samym być przeniesione na odbiorcę końcowego w taryfie. Elementem zniechęcającym do podejmowania takiego ryzyka jest również mechanizm współczynnika korekcyjnego, służącego obniżeniu taryfy ze względu na poprawę efektywności funkcjonowania przedsiębiorstwa (art. 9 rozporządzenia taryfowego). Oznacza on konieczność „dzielenia się” z odbiorcami oszczędnościami, jakie poczyniło przedsiębiorstwo energetyczne $\mathrm{w}$ zakresie swojego działania, w tym oszczędnościami $\mathrm{z}$ tytułu niższych kosztów nabycia paliwa gazowego. $\mathrm{Z}$ kolei jednak brak regulacji przenoszących ryzyko na odbiorcę z tytułu takiego zakupu gazu na giełdzie, który okazał się biznesowo niekorzystny. W tym zakresie art. 9 ust. 2 rozporządzenia taryfowego wprowadza również usztywnienie w postaci wprowadzenia „dopuszczalnych zmian cen lub stawek opłat na dany rok okresu regulacji”. Oznacza to brak jednakowego podejścia do generowanego zysku i straty przez przedsiębiorstwo kupujące gaz ziemny na giełdzie, co może zniechęcać do korzystania z takich platform obrotu, wbrew istniejącemu obligo giełdowemu nałożonemu na sprzedawcę ${ }^{40}$.

\section{ZMIANA MODELU RYNKU}

Nakazując sprzedaż określonej ilości gazu ziemnego poprzez giełdę, wzmocniono tę platformę obrotu hurtowego, ponieważ zagwarantowano, że odpowiednia ilość gazu ziemnego będzie dostępna na giełdzie $w$ ramach zestandaryzowanych produktów giełdowych. Obowiązek ten nałożono jednak w praktyce wyłącznie na jeden podmiot, który tworzy stronę podażową rynku. Tę lukę legislacyjną próbuje się wypełnić kolejnym projektem zmiany ustawy $\mathrm{PE}^{41}$, który wprowadza tak zwaną sukcesję generalną. Jest to konstrukcję prawna, na której podstawie w miejsce dotychczasowego sprzedawcy gazu dla gospodarstw domowych, małych i średnich przedsiębiorstw (zużywających w jednym punkcie odbioru do $25 \mathrm{mln} \mathrm{m}^{3}$ gazu rocznie) wchodzi z mocy ustawy inny podmiot. W pozostałym zakresie treść umowy się nie zmienia. Tak powołany nowy podmiot będzie konkurować $\mathrm{w}$ tym segmencie rynku $\mathrm{z}$ innymi podobnymi przedsiębiorstwami, co powinno pozytywie wpłynąć na jakość usług dla odbiorców.

Zmiana ta ma zapewnić płynne przejście do nowego modelu rynku przy niezakłóconym dostarczaniu gazu dla gospodarstw domowych i małych i średnich przedsiębiorstw na podstawie dotychczasowych umów, bez konieczności zawierania nowych umów przez około $6,7 \mathrm{mln}$ odbiorców, zużywających rocznie $9 \mathrm{mld}^{3}$ gazu ziemnego, czyli ponad 54\% krajowej konsumpcji. Konieczność podpisania kilku milionów nowych umów $\mathrm{w}$ bardzo krótkim czasie mogłaby bowiem prowadzić do

40 Zob. J. Antczak, Nie porażają doskonałościa, „Rzeczpospolita” 2001, PCD 2001/6/13 (SIP Lex nr 30421): „Regulator może uwzględnić w taryfie przedsiębiorstwa zysk, który ma służyć akumulacji środków niezbędnych na inwestycje modernizacyjne i rozwojowe. Nie ma natomiast mowy o zysku jako źródle wynagrodzenia właściciela za włożony kapitał i ponoszone ryzyko prowadzenia działalności”; S. Gronowski, Rozbieżność ocen, „Rzeczpospolita” 2000, PCD.2000.6.7 (SIP Lex nr 26389/1): „Ceny, opłaty oraz warunki ich stosowania zawarte w taryfie (por. art. 3 pkt 17 pr. energet.) powinny być na poziomie rzeczywiście niezbędnym ze względów technicznoorganizacyjnych lub ekonomicznych do prowadzenia przez przedsiębiorstwo energetyczne działalności gospodarczej. Poziom cen przewidziany w taryfie powinien uwzględniać także należytą staranność takiego przedsiębiorstwa (por. art. $355 \S 2$ k.c. i art. 40 ust. 2 pr. energet.)”.

41 Poselski projekt ustawy o zmianie ustawy - Prawo energetyczne, druk sejmowy 2389. 
pogorszenia sytuacji odbiorcy. Zmiana ta jest również odpowiedzią na rekomendację Prezesa UOKIK z 2012 r., który postulował rozdzielenie obrotu hurtowego i detalicznego na rynku gazu ziemnego, oraz odnosi się do Komunikatu Prezesa URE 21/2013, w którym uzależniał on dalsze etapy liberalizacji rynku od wejścia w życie przepisów gwarantujących publiczną sprzedaż gazu ziemnego. Sukcesja generalna była już zastosowana w 2007 r. na rynku energii elektrycznej, gdzie za pomocą takiego samego mechanizmu, przy poszanowaniu praw odbiorców, zapewniono wzmocnienie konkurencji na rynku. Pozytywne doświadczenia $\mathrm{z}$ tamtą zmianą mogą się również przełożyć na te wynikające $\mathrm{z}$ przedmiotowej nowelizacji. Zmiana ta powinna gwarantować niepogorszenie sytuacji odbiorców względem dotychczasowych warunków umowy -czyli jakości obsługi oraz ceny płaconej za gaz. Ma to być gwarantowane przez: (1) solidarną odpowiedzialność dotychczasowego sprzedawcy i nowego za zobowiązania względem odbiorcy, (2) obowiązywanie dotychczasowej taryfy PGNiG (czyli cen dla odbiorcy) do czasu uzgodnienia nowej z Prezesem URE, (3) zagwarantowanie odbiorcy możliwości wypowiedzenia umowy, o której to możliwości powinien być poinformowany.

Oznacza to, że mało prawdopodobne jest, że wprowadzona regulacja w zakresie obliga giełdowego zaktywizuje rynek hurtowy gazu ziemnego i doprowadzi do zmiany modelu całego rynku gazu. Brak bowiem bodźców po stronie popytowej rynku, aby taki mechanizm zafunkcjonował. Spowoduje to, że obligo będzie praktycznie realizowała jedna spółka, która handlować będzie $w$ ramach swojej grupy kapitałowej $\mathrm{z}$ wykorzystaniem pośrednika, jakim jest giełda. Inni uczestnicy rynku hurtowego, nie mając ani obowiązku, ani zachęt do kupowania lub sprzedawania gazu ziemnego za pośrednictwem tej platformy obrotu, zachowywać się będą tak, jak wynika to $\mathrm{z}$ wykształconych już mechanizmów obrotu hurtowego na innych rynkach europejskich, czyli podstawą obrotu będą kontrakty OTC, a obrót giełdowy będzie stanowił uzupełnienie pozycji kontraktowych. Ewentualna zmiana jest możliwa, jeżeli zlikwiduje się próg $10 \%$, nakazując wszystkim dokonywanie transakcji przez giełdę, albo wprowadzi się obowiązek zakupu określonych ilości gazu za pośrednictwem tej platformy obrotu, albo też wprowadzi się inne rozwiązania, zgodnie z którymi giełda tworzyć będzie faktyczną cenę referencyjną. Działania takie muszą być wsparte zaproponowaniem kompleksowego modelu rynku hurtowego, opartym na poszerzeniu oferty produktowej TGE.

\section{PODSUMOWANIE}

Obecna zależność Polski od dostawy gazu ziemnego z zagranicy jest korzystna na tle innych państw UE pod względem udziału produkcji własnej $\mathrm{w}$ całkowitej ilości konsumowanego w kraju gazu ziemnego i niekorzystna pod względem ilości źródeł i kierunków dostaw. Budowanie rynku hurtowego gazu ziemnego będzie wymagać zwiększenia dywersyfikacji w tym zakresie, która może osiągnąć akceptowalny poziom $\mathrm{w}$ perspektywie średnio- i długookresowej. Biorąc pod uwagę strukturę kontraktów importowych oraz możliwości dostaw, jest możliwe, że dojdzie do nadpodaży gazu na rynku krajowym. Sposobem na rozwiązanie tych problemów może być rozwinięty rynek hurtowy gazu. Wprowadzenie regulacji w zakresie obliga gazowego $\mathrm{w}$ obecnej formie nie jest jednak właściwym sposobem tworzenia tego rynku.

$\mathrm{Na}$ podstawie zapisów art. 49b ustawy PE można stwierdzić, że mechanizm zaproponowany w Polsce jawi się jako rozwiązanie unikatowe w skali Unii Europejskiej. Zaproponowano bardzo krótki okres na jego wdrożenie na wysokim poziomie $(40 \% \mathrm{w}$ 
2014 r. i 55\% w 2015 r. i latach następnych). Ustawodawca przyjął niespotykaną w innych państwach szybką ścieżkę zmiany modelu rynku, która oprócz kosztów i ryzyk po stronie przedsiębiorstwa zobowiązanego rodzi również możliwość powstania kosztów osieroconych, czyli kosztów powstałych w wyniku wprowadzania regulacji liberalizujących rynek, których przedsiębiorstwa nie są w stanie odzyskać na rynku konkurencyjnym. Tego rodzaju rozwiązania regulacyjne mogą wpływać na rentowność przedsiębiorstwa.

Rozwiązania te stwarzają również wątpliwości natury prawnej. Regulacja nakłada obowiązek znalezienia kupującego, który obarczony jest karą, co wykracza poza regulacje umowy sprzedaży, regulowanej w kodeksie cywilnym. Powstaje również ryzyko uznania takich zapisów za niemożliwe do wykonania, a tym samym sprzeczne z Konstytucją RP. Brak spójności zapisów z regulacjami w zakresie taryf i obecną strukturą rynku sprawia, że może ona powodować więcej barier w rozwoju rynku konkurencyjnego niż korzyści. Konieczne jest zaproponowanie spójnego modelu tej regulacji uwzględniającego kierunki rozwoju unijnego rynku hurtowego gazu ziemnego.

\section{LITERATURA}

[1]Antczak J., Nie porażają doskonatościa, , Rzeczpospolita” 2001, PCD 2001/6/13 (SIP Lex nr 30421).

[2]Bieniek G., Ciepła H., Dmowski S. i in. Komentarz do kodeksu cywilnego. Ksiega trzecia. Zobowiqzania, Lexis Nexis, Warszawa 2011.

[3]BP Statistical Review 2013 [na:] https://www.bp.com/content/dam/bp/pdf/statisticalreview/statistical_review_of_world_energy_2013.pdf (dostęp w dniu 31.03.2014).

[4]Dyrektywa Parlamentu Europejskiego i Rady 2009/73/WE z 13 lipca 2009 r. dotycząca wspólnych zasad rynku wewnętrznego gazu ziemnego i uchylająca dyrektywę 2003/55/WE (DzU L 211 z 14/08/2009, s. 94-136).

[5]Dyrektywa Parlamentu Europejskiego i Rady 98/30/WE z 22 czerwca 1998 r. dotycząca wspólnych zasad w odniesieniu do rynku wewnętrznego gazu ziemnego (DzU L 204 z 21/07/1998, s. 1-12).

[6]Gronowski S., Rozbieżność ocen, „Rzeczpospolita” 2000, PCD.2000.6.7 (SIP Lex nr 26389/1):

[7]Instrukcja Ruchu i Eksploatacji Sieci Przesyłowej OGP Gaz-System S.A., wersja nr 023 z listopada 2013 r., www.gaz-system.pl.

[8]Morawska E., Klauzula państwa prawnego $w$ Konstytucji RP na tle orzecznictwa Trybunału Konstytucyjnego, Dom Organizatora, Toruń 2003.

[9] Wyrok Trybunału Konstytucyjnego z dnia 9.10.2001 r. SK 8/2000, OTK ZU Nr 7 (45)/2001, s. 1035

[10] Poselski projekt ustawy o zmianie ustawy - Prawo energetyczne oraz niektórych innych ustaw, druk nr 946, www.sejm.gov.pl.

[11] Poselski projekt ustawy o zmianie ustawy - Prawo energetyczne, druk sejmowy 2389.

[12] Raport Krajowy Prezesa Urzędu Regulacji Energetyki za 2013 r., Warszawa lipiec 2013 r., www.ure.gov.pl/download/1/6634/Raport2013.pdf.

[13] Rozporządzenia Rady Ministrów z 24 października 2000 r. w sprawie minimalnego poziomu dywersyfikacji dostaw gazu $\mathrm{z}$ zagranicy, gdyż wpływa ono również na kierunki dywersyfikacji (Dz. U $2000 \mathrm{nr} 95$, poz. 1042).

[14] Rozporządzenie Ministra Gospodarki z 28 czerwca 2013 r. w sprawie szczegółowych zasad kształtowania i kalkulacji taryf oraz rozliczeń w obrocie paliwami gazowymi (Dz. U $2013 \mathrm{nr} 820$ ). 
[15] Rozporządzenie Parlamentu Europejskiego i Rady (WE) nr 715/2009 z 13 lipca 2009 r. w sprawie warunków dostępu do sieci przesyłowych gazu ziemnego i uchylające rozporządzenie (WE) nr 1775/2005 (Dz. U L 211 z 14/08/2009, s. 36-54).

[16] Ustawa z 10 kwietnia 1997 r. Prawo energetyczne (Dz. U 2012 nr 1059 jt., ze zm.).

[17] Ustawa dnia 26 lipca 2013 r. o zmianie ustawy - Prawo energetyczne oraz niektórych innych ustaw (Dz. U 2013 nr984).

[18] Ustawa z 16 lutego 2007 r. o ochronie konkurencji i konsumentów (Dz. U 2007 nr 50 poz. 331).

[19] Ustawa z 16 lutego 2007 r. o zapasach ropy naftowej, produktów naftowych i gazu ziemnego oraz zasadach postępowania $w$ sytuacjach zagrożenia bezpieczeństwa paliwowego państwa i zakłóceń na rynku naftowym (Dz. U 2012 poz. 1190).

[20] Ustawa z 26 października 2000 r. o giełdach towarowych (Dz. U 2014 nr 197 jt. ).

[21] Ustawa z 23 kwietnia 1964 r. Kodeks cywilny (Dz. U 2014 nr 121 jt.).

[22] Ustawa z 29 lipca 2005 r. o obrocie instrumentami finansowymi (Dz. U 2014 nr 94 jt.).

[23] Wyrok Naczelnego Sądu Administracyjnego z 23 kwietnia 2013 r., sygn. akt II GSK $51 / 2012$.

[24] Wyrok Naczelnego Sądu Administracyjnego z 23 kwietnia 2013 r., sygn. akt II GSK $51 / 2012$.

[25] Wyrok Sądu Apelacyjnego w Warszawie z 10 października 2012 r., sygn. akt VI ACa 398/2012.

[26] Wyrok Sądu Najwyższego z 1 czerwca 2010 r., sygn. akt III SK 5/2010.

[27] Wyrok Trybunału Konstytucyjnego z 13 marca 2007 r., sygn. akt K8/07.

[28] Wyrok Trybunału Konstytucyjnego z 29 listopada 2006 r., sygn. akt SK 51/06.

[29] Wyroki TK z 27.11.2007 r. U. 11/97, OTK ZU 5-6/14-15 (1997).

[30] Zajdler R., Legal Aspects of Electricity and Gas Interconnectors with Third Countries, [w:] EU Energy Law, Legal constraints with the implementation of Third Liberalisation Package, red. Robert Zajdler,_wyd. 1, Cambridge Scholars Publishing, Cambridge 2012.

[31] Zajdler R., Pespektywy rozwoju formut cenowych w kontraktach dlugoterminowych na dostawy gazu ziemnego oraz ich znaczenie dla stworzenia w Polsce hubu gazowego dla państw Europy Środkowo-Wschodniej, wyd. 1, Instytut Sobieskiego, Warszawa 2012.

[32] Zajdler R., Polski rynek hurtowy gazu ziemnego na tle rynków Unii Europejskiej, wyd. 1, Robert Zajdler Kancelaria Radcy Prawnego, Warszawa 2014.

[33] Załącznik do Uchwały nr 202/2009 Rady Ministrów z 10 listopada 2009 r. „Polityka energetyczna Polski do 2030 r.”.

CRITICAL NOTES TO THE REGULATORY MEASURES OF „EXCHANGE OBLIGATION" AS A METHOD OF CONSTRUCTION OF THE WHOLESALE NATURAL GAS MARKET IN POLAND

The aim of this article is to present legal analysis of regulatory solutions in terms of the sale of defined quantities of natural gas by the entities specified in the Act on commodity exchanges or market organized by the entity operating in the territory of the Republic of Poland regulated market. The market implications of proposed solutions are significant. The entity obliged has to sell natural gas under this mechanism in an amount not less than $30 \%$ in $2013,40 \%$ in 2014 and 55\% in 2015 and subsequent years. Non-fulfilment or inadequate fulfilment of this obligation is sanctioned up to $15 \%$ of the financial income from activities conducted by the entity on the basis of concessions in the previous fiscal year. These solutions raise legal uncertainties concerning their constitutional and administrative and civil law aspects regarding the admissibility of the method of regulation of contractual relations. The vagueness of certain terms may lead to its inadequate application. The costs of their introduction may adversely affect the market and its participants.

Considerations are embedded in the economic and geostrategic context of the natural gas market conditions in the European Union and in the structure of the domestic market. 
The proposed wholesale gas market model is different from that the one observed in other EU Member States. It may therefore cause barriers to further market development and integration of the domestic market of the European Union market. This paper will present suggested legal solutions, which in the opinion of the author can enhance the adopted model to the one existing in the European Union.

Keywords: natural gas, liberalisation, EU gas market, tariffs, gas exchange obligation, wholesale market

DOI:10.7862/rz.2014.hss.51

Przesłano do redakcji: czerwiec 2014

Przyjęto do druku: październik 2014 